\title{
Aetiology of exudative pleural effusion in clinical prospectus
}

\begin{abstract}
Khatun $\mathrm{A}^{1}$, Arif $\mathrm{SM}^{2}$, Islam $\mathrm{A}^{3}$

Pleural effusion is common medical problem in clinical practices. Because extensive investigation is needed for diagnosis of pleural effusion especially exudative pleural effusion. But in some cases it remains undiagnosed. Parapneumonic effusion more common in younger age, in developed countries tubercular pleural effusion is common in all age group. Above 60 years malignant pleural effusion is suggested. This cross sectional study was conducted on department of respiratory medicine and department of Medicine in Dhaka Medical College Hospital (DMCH) during the period of January 2017 to July 2017. Clinically suspected 100 patients were enrolled in this study. Aetiology of pleural effusion was confirmed by clinical and laboratory diagnosis like x-ray, cytology, biopsy. This study showed $28(28 \%)$ were diagnosed as parapneumonic pleural effusion, $47(47.0 \%)$ as tubercular pleural effusion which was confirmed by ADA level and gene expert, 14(14\%) were malignant pleural effusion was confirmed by histopathology of biopsy material and $11(11 \%)$ as undiagnosed pleural effusion. Among malignant pleural effusion, adenocarcinoma was $71.42 \%$, large cell carcinoma was $14.28 \%$, both small cell carcinoma and mesothelioma is $7.14 \%$.
\end{abstract}

CBMJ 2018 January: vol. 07 no. 01 P: 30-34

Key words: EPE (Exudative pleural effusion), ADA (Adenosine deaminase)

\section{Introduction}

Pleural effusions is two type, transudative (TPE) and exudative (EPE) ${ }^{1,2}$. It is the most common problem in clinical practice ${ }^{3}$. EPE needs extensive evaluation and treatment more than that of transudative pleural effusion ${ }^{2}$. About $22 \%$ EPE remains undiagnosed and the most common causes of undiagnosed EPE are tuberculosis and malignancy ${ }^{2,3}$. In developed countries parapneumonic effusion is the most common in younger age group whereas in developing countries tubercular effusion is the most common in younger age group. Usually above 60 years EPE suggests malignancy ${ }^{4}$. Successful treatment depends on detection of exact aetiology, because it is a common diagnostic problem ${ }^{5}$.

Sharp localizing chest pain which is worse on twisting or bending of body radiating to the upper abdomen or shoulder, deep inspiration, dry and non productive cough with hemoptysis may suggestive of endobronchial cancer or pulmonary thromboembolism ${ }^{5}$. On physical examination, tactile fremitus in palpation is either absent or attenuated, and the percussion note over a pleural effusion is stony dull or flat. In auscultation, the breath sounds are decreased or absent, and auscultatory percussion (Guarino's second method) is abnormal ${ }^{6}$.

By clinical examination diagnostic procedure is started, then chest X-rays, pleural fluid analysis and pleural biopsy is the next step ${ }^{7}$. Posterioranterior and lateral chest radiographs usually confirm the presence of EPE. If doubt exists, ultrasound or computed tomography (CT) scans are definitive for detecting small effusions ${ }^{2}$. Physical, Biochemical, Microbiological, Cytological study, and Adenosine deaminase (ADA) of pleural fluid, traditional tuberculin skin test, sputum smear microscopic examination of acid fast bacilli (AFB) and pleural biopsy need to confirm $\mathrm{EPE}^{2,3,8}$. Predominate numbers of neutrophils, high LDH activity (>200 U/L) and protein level $(>3 \mathrm{~g} / \mathrm{dl})$ in a

1. Dr. Amena Khatun, Registrar. Medicine Unit 1, Community Based Medical College Bangladesh.

2. Syed. Md. Arif, Associate Professor, Medicine unit Dhaka Medical College Hospital.

3. Dr. Arup Islam; Assistant Professor, Department of Microbiology, Mymensingh Medical College

Address of correspondence:

Email:dr.chumkicbmc@gmail.com Mobile: 01721700381 
pleural effusion indicate bacterial pneumonia 9 . Pleural fluid CRP level $>1.38 \mathrm{mg} / \mathrm{dl}$ indicates the strong possibility of a parapneumonic effusion ${ }^{10}$. Pleural biopsy provides diagnostic evidence for both tuberculosis and malignancy ${ }^{3}$. Higher RBC counts and lower adenosine deaminase (ADA) activity in pleural fluid resembling malignancy 9 . This study is to relate EPE with clinical manifestation and laboratory investigation for early diagnosis of diseases in patients. It will help in prompt treatment of patients that can shorten the hospital stay and less burden of economy of the patients.

\section{Materials and Methods}

Study Design: Cross-sectional Observational study

Place of Study: Department of respiratory medicine and Department of Medicine inDhaka Medical College Hospital (DMCH).

Study Period: January 2017 to July 2017.

Study population: Patient admitted on indoor medicine unit with exudative pleural effusion of Dhaka Medical College Hospital.

Sampling Method: Purposive Convenient Sampling.

Sample size: 100

\section{Results}

The findings of the study are described as follows in the tables, figures and texts.

Table- 1: Categories of study population based on pleural effusion findings

\begin{tabular}{|l|c|c|c|c|}
\hline $\begin{array}{l}\text { Study } \\
\text { population } \\
(\mathbf{N}=100)\end{array}$ & $\begin{array}{c}\text { Parapneumonic } \\
\text { pleural effusion }\end{array}$ & $\begin{array}{c}\text { Tubercular } \\
\text { pleural } \\
\text { effusion }\end{array}$ & Malignant & Undiagnosed \\
\hline $100(100 \%)$ & $28(28.0 \%)$ & $47(47.0 \%)$ & $14(9 \%)$ & $11(11 \%)$ \\
\hline
\end{tabular}

Among 100 cases, 28(28\%) were diagnosed as parapneumonic pleural effusion, $47(47.0 \%)$ as tubercular pleural effusion, $14(14 \%)$ were malignant pleural effusion and $11(11 \%)$ as undiagnosed pleural effusion shows on table- 1
Table- 2: Age distribution of the study population $(\mathrm{N}=100)$

\begin{tabular}{|c|c|c|c|c|c|}
\hline $\begin{array}{c}\text { Age } \\
\text { group }\end{array}$ & $\begin{array}{c}\text { Parapneumonic } \\
\text { pleural } \\
\text { effusion } \\
(\mathrm{n}=28)\end{array}$ & $\begin{array}{c}\text { Tubercular } \\
\text { pleural } \\
\text { effusion } \\
(\mathrm{n}=47)\end{array}$ & $\begin{array}{c}\text { Malignant } \\
(\mathrm{n}=14)\end{array}$ & $\begin{array}{l}\text { Undiagnosed } \\
(\mathrm{n}=11)\end{array}$ & Total \\
\hline $18-40$ & $17(17.0)$ & $18(18.0)$ & 00 & $02(2.0)$ & $47(47.0)$ \\
\hline $41-60$ & $07(7.0)$ & $23(23.0)$ & $02(2.0)$ & $08(8.0)$ & $40(40.0)$ \\
\hline $61-65$ & 00 & $06(6.0)$ & $12(12.0)$ & $01(1.0 \%)$ & $19(19.0)$ \\
\hline $\begin{array}{c}\text { Total } \\
(\mathrm{N}=100)\end{array}$ & $28(28.0)$ & $47(47.0)$ & $14(14.0)$ & $11(11.0)$ & $\begin{array}{c}100 \\
(100.0)\end{array}$ \\
\hline
\end{tabular}

Figures in parentheses indicate percentage.

Most of the cases of study population were in the age group 18 to 40 years (47.0\%). Among 47 patient tubercular were 18, parapneumonic were 17 and undiagnosed were $2(2.0 \%)$. In this table age group 61 to 65 years (19.0\%). Among 19 patient tubercular were 6(6.0), malignant were 12 (12.) and undiagnosed were $1(1.0 \%)$ shows on table- 2

Table -03 showing the biopsy finding of malignant pleural effusion $(n=14)$

\begin{tabular}{|l|c|}
\hline Biopsy finding & Total \\
\hline Adenocarcinoma & $08(57.4 \%)$ \\
\hline Large cell carcinoma & $03(21.4 \%)$ \\
\hline Small cell carcinoma & $02(14.28 \%)$ \\
\hline Mesothelioma & $01(7.14 \%)$ \\
\hline
\end{tabular}

Biopsy of pleura reveal adenocarcinoma was $57.4 \%$, large cell carcinoma $21.4 \%$, small cell carcinoma $14.28 \%$ and mesothelioma was $7.14 \%$ shows on table- 3 Table- 04 Findings of leucocyte in different pleural effusion

\begin{tabular}{|c|c|c|}
\hline Investigation & \begin{tabular}{|c|}
\multicolumn{1}{c}{ Total } \\
Neutrophil $/ \mathrm{mm}^{3}$ \\
found mean $\pm S D$
\end{tabular} & $\begin{array}{c}\text { Lymphocyte } / \mathrm{mm}^{3} \\
\text { found } \\
\text { mean } \pm S D\end{array}$ \\
\hline $\begin{array}{l}\text { Parapneumonic pleural } \\
\text { effusion }(n=28)\end{array}$ & $1228.57 \pm 495.05$ & $229.64 \pm 85.60$ \\
\hline $\begin{array}{l}\text { Tubercular pleural } \\
\text { effusion }(n=47)\end{array}$ & $98.72 \pm 46.56$ & $472.34 \pm 199.40$ \\
\hline $\begin{array}{l}\text { Malignant pleural } \\
\text { effusion }(n=14)\end{array}$ & $171.42 \pm 72.62$ & $500.00 \pm 156.89$ \\
\hline $\begin{array}{l}\text { Undiagnosed pleural } \\
\text { effusion }(n=11)\end{array}$ & $333.33 \pm 57.79$ & $250.00 \pm 92.58$ \\
\hline
\end{tabular}

4. Data were analyst using Students Test; presented as Mean \pm SD. 
The cytological examination, where neutrophil predominant in Parapneumonic pleural effusion mean \pm SD1228.57 \pm 495.05, lymphocyte predominant in tubercular (472.34 \pm 199.40) and mean \pm SD500.00 \pm 156.89 malignant pleural effusion, in undiagnosed pleural effusion found both neutrophil and lymphocyte is predominate showing on table - 04

Table- 05 Comparison to detection of etiology of lymphocyte predominate pleural effusion by cytological examination, ADA level, protein level, LDH level

\begin{tabular}{|l|l|l|l|l|l|}
\hline \multicolumn{2}{|c|}{ Diagnostic group } & N & Mean & $\begin{array}{l}\text { Standard } \\
\text { Deviation }\end{array}$ & P value \\
\hline \multirow{2}{*}{ ADA level } & Tuberculosis & 47 & 53.59 & 10.14 & \multirow{2}{*}{0.0001} \\
\cline { 2 - 6 } & Malignant & 14 & 28.2 & 15.31 & \\
\hline $\begin{array}{l}\text { Cytological } \\
\text { finding } \\
\text { (lymphocyte) }\end{array}$ & Muberculosis & 47 & 472.34 & 199.34 & \multirow{2}{*}{0.6358} \\
\cline { 2 - 6 } & Malignant & 14 & 500.00 & 156.89 & \\
\hline Age group & Tuberculosis & 47 & 43.70 & 13.94 & \multirow{2}{*}{$<0.0001$} \\
\cline { 2 - 6 } & Malignant & 14 & 62.57 & 2.53 & \\
\hline
\end{tabular}

*Data were analyst using Student's Test.

It was revealed that in ADA level tubercular and malignant effusion (53.59 \pm 10.14 vs $28.2 \pm 15.31, \mathrm{p}=<0.0001)$ and cytological finding (472.34 \pm 3.68 vs $500.00 \pm 156.89$ $\mathrm{p}=0.6358$ and in age group (43.70 \pm 13.94 vs. $62.57 \pm 2.53$ years, $p=<0.0001)$ shows on table- 5

\section{Discussion}

Light's criteria (protein level $>3 \mathrm{gm} / \mathrm{dl}$ and LDH level >200ID/L) differ the exudative pleural effusion from transudative pleural effusion ${ }^{14}$. TB is the leading cause of pleural effusion in some countries ${ }^{15}$. In 2016 according to WHO, Bangladesh is one of TB burden country in 30 highest TB burden country ${ }^{16}$.

The phenomenon of the study is supported by International Journal of Advances in Medicine of Parikh P. et al in $2016^{11}$ and 'International Journal of Medical Science and Public Health' by Bamaniya D. et al in $2014^{17}$. In this study, among 100 cases majority of the patients was tubercular pleural effusion (47\%), parapneumonic was $28 \%$, malignant was $14 \%$ and rest of undiagnosed.
Age group of the patient was supported by Porikh $\mathrm{P}$, et $a l^{12}$. Another study 'Parapneumonic effusions: epidemiology and predictors of pleural infection' by Finch $\mathrm{S}$. and Chalmers J. found parapneumonic effusion more common in young and middle age $(18-50)^{18}$.

The tubercular age group of this study is similar to the 'Role of ADA in differential diagnosis of pleural effusion by Jasani $\mathrm{H}$. et $\mathrm{al}^{16}$ and another original article 'Analytical study of clinical and etiological profile of patients presenting with pleural effusion to a tertiary hospital' by Reddy A., et $\mathrm{al}^{19}$. Mean age group of tubercular pleural effusion and malignant pleural effusion, is statistically significant ( $p$ value $>0.0001$ ). The study by Mohan KM. and CR. found age group is statistically significant 20 . In this present study clinical finding is supported by Godwin CM. et $a^{21}$.

As per study, neutrophil predominant pleural fluid considered as parapneumonic effusion and predominance of lymphocyte in pleural fluid considered as tubercular or malignant pleural effusion. Because neutrophil predominant pleural fluid is indicating acute inflammatory process like pneumonia and in case of chronic disease like most of tubercular and malignant pleural fluids are lymphocyte predominance ${ }^{22}$.

Tuberculosis is one of the causes of lymphocytic pleural effusion but malignancy, lymphoma, collagen vascular diseases and chylothorax is also responsible for lymphocytic pleural effusion ${ }^{23}$. Pleural fluid with raised protein level $(>3 \mathrm{gm} / \mathrm{l})$, high lymphocyte count and ADA level is more than 40 indicate tubercular pleural effusion with sensitivity $90 \%$ and specificity $93 \%{ }^{24,25}$. In high prevalent TB area ADA test support the diagnosis ${ }^{13,26}$. The mean average range of ADA level in tubercular and in malignant pleural effusion, which is statistically significant as similar to Afrasiabian S. et al 23

As per this study, pleural biopsy shows that adenocarcinoma is maximum $(71.42 \%)$, large cell carcinoma $14.28 \%$, small cell and 
mesothelioma is $7.14 \%$. Mohan KM. et al and Ramesh $\mathrm{P}$. et al found adenocarcinoma is maximum ${ }^{20,27}$.

\section{Conclusion}

TB is the most common cause of pleural effusion in Bangladesh, the aetiology is revealed by that study. Cytological examination such as leukocyte examination can differ the acute case like parapneumonic effusion and chronic case like TB, malignancy. Now a days ADA level in pleural fluid, gene expert is used for diagnosis of pleural TB and in case of malignant pleural effusion histopatholgy, biopsy were done. Early diagnosis can less the hospital stay, patient burden and economical benefit of the patient.

\section{References}

1. Bartter T, Akers SA, Pretter MR. Evaluation of pleural fluid. Chest 1994;106:1209-1210.

2. Porcel JM, Light RW. Diagnostic Approach to Pleural Effusion in Adults. American Family Physician. 2006; 73:1211-20.

3. Solooki M, Miri M. Approach to undiagnosed exudative pleural effusion: the diagnostic yield of blind pleural biopsy. Caspian J Intern. 2013;4: 642-647.

4. Agarwal R, Tiwari V, Agarwal R, Gupta N. Study of Aetiological and Clinical Profile of Pleural Effusion in a Teritary Care Hospital . GJRA 2016; 5:33-34.

5. Rehan M, Alam MT, Aurangzeb M, Imran K et al. Frequency of various diseases in patients presenting with pleural effusion. Gomal J Med Sci 2013;11:78-83.

6. Na MJ. Diagnostic Tools of Pleural Effusion. Tuberc Respi Dis. 2014;76 :199-210.

7. Devkota KC, Chokhani R, Gautam S. Diagnostic yield of pleural biopsy in exudative pleural effusion. Nepal Med Coll J 2014;16:13-16.

8. Gabhale SD, Pallavi T, Yadav D et al. Usefulness of pleural fluid CRP level in differential diagnosis of exudative pleural effusion -. Int J Bio Res. 2015;2:97-109.

9. Rehan M, Alam MT, Aurangzeb M, Imran K, et al. Frequency of various diseases in patients presenting with pleural effusion. Gomal J Med Sci 2013;11:78-83.
10. Izhakian S, Wasser WG, Fox BD et al. The Diagnostic Value of the Pleural Fluid CRP in Parapneumonic Effusions. Disease Markers. 2016;7539780:1-6.

11. Saguil $A$, Wyrick $K$ and Hallgren $J$. Diagnostic Approach to Pleural Effusion. American Family Physician. 2013; 90:99-104.

12. Parikh $P$, Odhwani $J$ and Ganagajalia $C$. Study of 100 cases of pleural effusion with reference to diagnostic approach. International Journal of Advances in Medicine. 2016;328-331.

13. Karkhanis $V$ and Joshi J . Pleural effusion: diagnosis, treatment, and management. Open Access Emergency Medicine. 2012;31.

14. Bansiwal B, Saxena A, Jelia M, Kumar S and Kalera M. Etiological Diagnosis of Pleural Effusion by Pleural Fluid Examination. Scholars Journal of Applied Medical Sciences. 2016;4:2643-2648.

15. Hou F, Qi X, Ning Z, Zhao J, Zhang X., Deng $H$, Peng Y, Li J, Yao H, Li H and Guo $X$. Prevalence, risk factors, and in-hospital outcome of pleural effusion in liver cirrhosis: a retrospective observational study. Int $J$ Clin Exp Med. 2016; 9:3265-3279.

16. http://www. who.int/tb/data

17. Mohan KM and CR. Etiology and clinical profile of pleural effusion in a teaching hospital of south India: A descriptive study. Pulmon. 2012;14:89-97.

18. Finch $S$ and Chalmers J. Parapneumonic effusions: epidemiology and predictors of pleural infection. Current Respiratory Care Reports. 2014; 3(2), pp.52-60.

19. Reddy A, Raj G, Badusha M, Reddy C, Yugandhar $P$, Nilofer $S$ and Sri S. Analytical study of clinical and etiological profile of patients presenting with pleural effusions to a tertiary hospital. Journal of Evolution of Medical and Dental Sciences. 2015;4(88), pp.15305-15312.

20. Mohan KM and CR. Etiology and clinical profile of pleural effusion in a teaching hospital of south India: A descriptive study. Pulmon. 2012;14(3), pp.89-97.

21. Godwin CM, Benneth CA, Eugenia OO, Ernest CO, Innocent IC and Emmanuel NA. Pleural Effusion: Aetiology, Clinical Presentation and Mortality Outcome in a Tertiary Health Institution in Eastern Nigeria A Five Year Retrospective Study. J AIDS Clin Res. 2015; 6(2), pp.426-430. 
22. M. Porcel J. The Diagnostic Utility of Pleural Fluid Tests in Clinical Practice. Current Respiratory Medicine Reviews. 2012; 8(5), pp.383-390.

23. Afrasiabian S, Mohsenpour B, Haji Bagheri K, Sigari $N$ and Aftabi K. Diagnostic value of serum adenosine deaminase level in pulmonary tuberculosis. J Res Med Sci. 2013; 18(3), pp.252-254.

24. Cohen and Light $R$. Tuberculous Pleural Effusion. Turkish Thoracic Journal/Türk Toraks Dergisi. 2015;16(1), pp.1-9.

25. Parikh $P$, Odhwani $J$ and Ganagajalia $C$. Study of 100 cases of pleural effusion with reference to diagnostic approach. International Journal of Advances in Medicine. 2016; pp.328-331.
26. H. Jasani J, Mavadia S, Bansal N, Chandra $A$, Vacchani $D$, Champaneria $N$ and Patel $K$. Role of $A D A$ in the Differential Diagnosis of Pleural Effusion. International Journal of Health Sciences \& Research. 2016;6(10), pp.76-81.

27. Hadizadeh Talasaz Z, M.Lari S, Basiri R, Towhidi M, Attaran D, Asnaashari $A$ and Javid-Arabshahi Z. The Diagnostic Values of Protein to Lactate Dehyrogenase Ratio in Serum and Pleural Fluid in Exudate Pleural Effusions. Journal of Cardio -Thoracic Medicine. 2017;1(2), pp.42-46. 